\title{
PENERAPAN ANALISIS KONJOIN RANCANGAN FULL PROFILE DENGAN JENIS RESPON RANKING PADA PREFERENSI MAHASISWA TERHADAP KUALITAS DOSEN SEKOLAH TINGGI ILMU STATISTIK
}

\author{
Fitri Catur Lestari
}

\author{
Sekolah Tinggi Ilmu Statistik \\ fitricaturlestari@yahoo.com
}

\begin{abstract}
The lecturer is a component in university that has a great role to determine the quality of university. The lecturer quality evaluation is important because of that role. The students who are involved in a learning process should give an evaluation of the lecturer quality by preference. The method that concerns in preference study is conjoint analysis. The conjoint analysis consists of some steps: problem identification, stimuli designs, data collecting, choosing the procedure, and interpretation. The stimuli designs in this research is full profile and the data are collected as ranking respons by interview. The sampling method is purpossive. The samples are selected according to segmentation that are regarded varies among students preference to the quality of lecturer: GPA, level/class, origin of senior high school, gender, and the economic condition(income) of the parents. Based on the relative attribute importance, the students preference of the lecturer quality are: mastery of lecture material, ability to motivate students, character, communication, and learning method. The students preference of lecturer quality differs in segments: GPA, level/class, origin of senior high school, gender, and the economic condition(income) of the parents.
\end{abstract}

Keywords: conjoint analysis, full profile, preference

ABSTRAK. Dosen merupakan komponen dalam perguruan tinggi yang mempunyai peran sangat besar dalam menentukan kualitas perguruan tinggi. Evaluasi terhadap kualitas dosen dianggap penting karena perannya tersebut. Mahasiswa sebagai pihak yang terlibat langsung dengan dosen dalam proses pembelajaran layak untuk memberikan evaluasi dalam bentuk preferensi. Metode yang secara khusus mengkaji tentang preferensi adalah analisis konjoin. Langkah dalam analisis konjoin adalah merumuskan masalah, merancang stimuli, menentukan metode pengumpulan data, memilih prosedur analisis konjoin, dan interpretasi hasil. Pendekatan untuk merancang stimuli dalam penelitian ini yaitu full profile. Sedangkan metode pengumpulan data yang digunakan adalah wawancara dengan jenis data respon ranking. Adapun metode penarikan sampelnya adalah metode purpossive sampling dengan pemilihan sampel didasarkan pemerataan pada segmen yang diduga terdapat perbedaan preferensi mahasiswa terhadap kualitas dosen yaitu IPK, tingkat/kelas, asal SMA, jenis kelamin, dan kemampuan ekonomi (pendapatan) orang tuanya. Berdasarkan Nilai Relatif 
Penting (NRP), preferensi mahasiswa terhadap kualitas dosen yaitu penguasaan materi kuliah, kemampuan memotivasi mahasiswa, pembawaan diri, penyampaian materi, dan metode pembelajaran. Preferensi mahasiswa terhadap kualitas dosen berbeda-beda menurut segmen IPK, tingkat/kelas, asal SMA, jenis kelamin, dan kemampuan ekonomi (pendapatan) orang tuanya.

Kata Kunci: analisis konjoin, full profile, preferensi

\section{PENDAhuluan}

Dosen sebagai salah satu komponen Sumber Daya Manusia (SDM) dari suatu perguruan tinggi mempunyai peran sentral dan strategis. Pentingnya peran dosen dinyatakan oleh Sudiana (2003) bahwa dosen sebagai salah satu komponen perguruan tinggi berperan sangat besar dalam mewujudkan kualitas perguruan tinggi. Faktor kualitas dosen juga terbukti berpengaruh signifikan terhadap motivasi belajar mahasiswa dengan tingkat signifikansi 0,01 dan memiliki korelasi yang paling kuat di antara faktor yang lain (Pujadi, 2007). Bidang kegiatan dosen melaksanakan pendidikan dan pengajaran merupakan bidang yang lebih utama di antara 2 (dua) bidang lainnya yaitu penelitian, dan pengabdiaan kepada masyarakat (DPPM, 2002). Kualitas dosen pada bidang pendidikan dan pengajaran merupakan faktor yang menentukan kualitas perguruan tinggi.

Mahasiswa sebagai konsumen atau pihak yang berkepentingan (stakeholders) terhadap dosen pada proses belajar mengajar, layak untuk memberikan evaluasi terhadap kualitas dosen. Suatu penilaian berkaitan dengan kepuasan dan preferensi. Suatu penilaian akan tinggi ketika kepuasan tinggi dan kepuasan tinggi sangat dipengaruhi oleh preferensi. Chaplin (2002) mendefinisikan preferensi sebagai suatu sikap yang lebih menyukai sesuatu benda daripada benda lainnya. Dalam penelitian ini, preferensi diartikan sebagai suatu sikap yang lebih menyukai karakteristik dosen tertentu dibandingkan dengan karakteristik dosen yang lainnya. Selanjutnya akan dikaji preferensi tersebut berdasarkan segmen karakteristik mahasiswa: Indeks 
Prestasi Kumulatif (IPK), tingkat/kelas, asal SMA, jenis kelamin, dan kemampuan ekonomi (pendapatan) orang tua.

Hasil penelitian ini dapat dimanfaatkan sebagai bahan acuan bagi dosen dalam kegiatannya melaksanakan pendidikan dan pengajaran. Selain itu, mahasiswa juga dapat menggunakan hasil penelitian ini untuk mengoptimalkan proses pembelajarannya di perguruan tinggi. Pihak perguruan tinggi juga dapat menyusun suatu kegiatan evaluasi kualitas dosen berdasarkan preferensi mahasiswa yang dipaparkan dalam penelitian ini.

\section{METODE PENELITIAN}

\subsection{Perumusan masalah}

Langkah awal dalam melakukan analisis konjoin yaitu perumusan masalah (Aaker et. al., 1980). Perumusan masalah dimulai dari mendefinisikan produk sebagai kumpulan dari atribut-atribut dimana setiap atribut terdiri atas beberapa taraf/level. Informasi mengenai atribut yang mewakili preferensi konsumen bisa diperoleh melalui diskusi dengan pakar, eksplorasi data sekunder, atau melakukan tes awal (Rosada, 2002).

Kualitas dosen diwujudkan dalam suatu karakteristik atau atribut yang terdiri atas taraf-taraf. Atribut dan taraf dosen dalam studi ini ditetapkan dengan melakukan tes awal atau penelitian pendahuluan. Berikut ini tabel hasil penelitian pendahuluan dalam penentuan atribut dan taraf: 
Tabel 1 Atribut yang Mempengaruhi Preferensi Mahasiswa terhadap Kualitas Dosen

\begin{tabular}{|l|l|r|}
\hline No. & \multicolumn{1}{|c|}{ Atribut } & Persentase \\
\hline 1 & Penyampaian materi & $24,00 \%$ \\
\hline 2 & Metode mengajar kreatif dan inovatif & $20,00 \%$ \\
\hline 3 & Penguasaan materi & $19,00 \%$ \\
\hline 4 & Pembawaan diri & $11,50 \%$ \\
\hline 5 & Suka memotivasi & $9,00 \%$ \\
\hline 6 & Penilaian obyektif & $5,50 \%$ \\
\hline 7 & Sistematika & $3,00 \%$ \\
\hline 8 & Pendidikan & $2,00 \%$ \\
\hline 9 & Wibawa & $2,00 \%$ \\
\hline 10 & Pengelolaan kelas & $2,00 \%$ \\
\hline 11 & Penampilan & $1,50 \%$ \\
\hline 12 & Penggunaan bahan ajar & $1,00 \%$ \\
\hline 13 & Umur & $0,00 \%$ \\
\hline
\end{tabular}

Berdasarkan tabel 1, terdapat 5 (lima) atribut yang persentasenya relatif tinggi yaitu berkisar $9,00 \%$ sampai $24,00 \%$. Adapun kelima atribut ini masing-masing terdiri atas 2 (dua) taraf dengan perincian : penyampaian materi kuliah (komunikasi dua dan satu arah), metode pembelajaran (kreatif dan tidak kreatif), penguasaan materi kuliah (menguasai dan tidak menguasai), pembawaan diri (humoris dan serius), dan kemampuan memotivasi mahasiswa (memotivasi dan tidak memotivasi).

\subsection{Perancangan Stimuli}

Rancangan kombinasi yang akan digunakan dalam penelitian ini disusun berdasarkan kombinasi lengkap (full profile) atau evaluasi banyak faktor (http://www.sawtooth.com, 2001). Karena terdapat 5 (lima) atribut maka terdapat $2^{5}$ atau 32 kartu. Pada tahap ini juga disusun pertanyaan yang berkaitan dengan peubah demografi dalam bentuk kuesioner untuk mengetahui karakteristik mahasiswa. Hal ini memungkinkan adanya temuan tentang segmen mahasiswa berdasarkan preferensinya terhadap kualitas dosen. 


\subsection{Pengumpulan Data}

Data pada penelitian ini merupakan data primer yang dikumpulkan melalui survei berbasis wawancara dengan menggunakan kuesioner dan kartu-kartu stimuli yang berisi tentang karakteristik atau profil yang menggambarkan kualitas dosen (dalam hal ini pengajar mata kuliah eksak). Kartu-kartu stimuli tersebut dievaluasi oleh mahasiswa dalam bentuk ranking (urutan). Penelitian dilakukan di STIS pada Rabu-Kamis, 20-21 Juli 2011 dengan melibatkan 125 mahasiswa STIS tahun akademik 2010/2011 yang dipilih berdasarkan metode purpossive sampling. Metode purpossive sampling adalah salah satu metode penarikan contoh tak berpeluang dengan mengumpulkan informasi dari sumber yang tepat di antaranya anggota masyarakat yang dipandang dapat memberikan informasi yang dibutuhkan atau hanya mereka yang dirasa dapat memberikan informasi yang kita butuhkan (Wibisono, 2003). Pemilihan sampel juga didasarkan pemerataan pada segmen yang diduga terdapat perbedaan preferensi mahasiswa terhadap kualitas dosen yaitu IPK, tingkat/kelas, asal SMA, jenis kelamin, dan kemampuan ekonomi (pendapatan) orang tuanya.

\subsection{Prosedur Analisis}

Prosedur analisis yang digunakan dalam penelitian ini adalah metode regresi dengan variabel dummy. Adapun secara umum model dasar analisis konjoin (Kuhfeld, 2000) dengan prosedur analisis tersebut adalah:

$$
Y_{i j}=\beta_{0}+\sum_{i=1}^{m} \sum_{j=1}^{k} \beta_{i j} X_{i j}+\varepsilon_{i j}
$$

Keterangan :

$Y_{i j} \quad=$ Peringkat seluruh responden

$\beta_{o} \quad=$ Intersep

$k=$ Banyak taraf dari atribut ke- $i$

$m \quad=$ Jumlah atribut

$X_{i j} \quad=$ Peubah boneka atau dummy variable dari atribut ke-i taraf ke-j

$\beta_{i j} \quad=$ Part worth atau nilai kegunaan atribut ke-i taraf ke-j

$\varepsilon_{i j} \quad=$ Galat 
Dengan model regresi tersebut, maka dapat ditentukan nilai kegunaan dari taraf-taraf tiap atribut (NKT) untuk menentukan nilai pentingnya suatu taraf relatif terhadap taraf yang lain pada suatu atribut. Setelah menentukan NKT, maka Nilai Relatif Penting (NRP) dapat dihitung dengan formula sebagai berikut:

$$
N R P_{i}=\frac{U T_{i}-U R_{i}}{\sum_{i=1}^{k}\left(U T_{i}-U R_{i}\right)}
$$

Keterangan:

$N R P_{i}=N R P$ atribut ke-i

$U T_{i} \quad=$ NKT tertinggi atribut ke-i

$U R_{i} \quad=N K T$ terendah atribut ke-i

$k=$ Jumlah atribut

Data preparation dan analisis tersebut dilakukan dengan menggunakan software pengolah data: SPSS 13.0, Microsoft Excel 2003, dan SAS versi 9.1.

\section{HASIL DAN PEMBAHASAN}

\subsection{Preferensi Mahasiswa terhadap Kualitas Dosen}

Berdasarkan hasil pengolahan data, atribut yang paling mempengaruhi preferensi mahasiswa terhadap kualitas dosen adalah penguasaan materi kuliah dengan Nilai Relatif Penting (NRP) sebesar 31,05\%. Atribut berikutnya adalah kemampuan memotivasi mahasiswa, pembawaan diri, penyampaian materi, dan metode pembelajaran dengan NRP berturut-turut $21,01 \%, 20,29 \%, 17,44 \%$ dan $10,21 \%$. Dosen yang paling disukai oleh mahasiswa adalah dosen yang menguasai materi kuliah karena Nilai Kegunaan Taraf (NKT) paling tinggi di antara taraf lainnya yaitu 9,20. Dosen berikutnya yang disukai secara berturut-turut adalah dosen yang mampu memberi motivasi kepada mahasiswanya (NKT=6,23), humoris (NKT=6,01), menyampaikan materi dengan komunikasi dua arah $(\mathrm{NKT}=5,17)$, dan metode pembelajarannya kreatif $(\mathrm{NKT}=3,03)$. Berikut ini tabel yang berkaitan dengan NKT dan NRP yang dihasilkan: 
Tabel 2 Hasil Prosedur Analisis

\begin{tabular}{|c|c|c|c|c|c|c|}
\hline No. & Atribut & Taraf & $\begin{array}{c}\text { Nilai } \\
\text { Kegunaan } \\
\text { Taraf }\end{array}$ & Jarak & $\begin{array}{c}\text { Nilai } \\
\text { Relatif } \\
\text { Penting }\end{array}$ & Urutan \\
\hline & \multirow{2}{*}{$\begin{array}{l}\text { Penyampaian } \\
\text { materi }\end{array}$} & a. Komunikasi dua arah & 5,17 & \multirow{2}{*}{10,34} & \multirow{2}{*}{$17,44 \%$} & \multirow{2}{*}{4} \\
\hline & & b. Komunikasi satu arah & $-5,17$ & & & \\
\hline & Metode & a. Kreatif & 3,03 & \multirow{2}{*}{6,05} & \multirow{2}{*}{$10,21 \%$} & \multirow{2}{*}{5} \\
\hline & pembelajaran & b. Monoton & $-3,03$ & & & \\
\hline \multirow{3}{*}{3.} & \multirow{3}{*}{$\begin{array}{l}\text { Penguasaan materi } \\
\text { kuliah }\end{array}$} & a. Menguasai materi & 9,20 & \multirow{3}{*}{18,40} & \multirow{3}{*}{$31,05 \%$} & \multirow{3}{*}{1} \\
\hline & & & $-9,20$ & & & \\
\hline & & b. Tidak menguasai materi & & & & \\
\hline \multirow{2}{*}{4.} & \multirow{2}{*}{ Pembawaan diri } & a. Humoris & 6,01 & \multirow{2}{*}{12,03} & \multirow{2}{*}{$20,29 \%$} & \multirow{2}{*}{3} \\
\hline & & b. Serius & $-6,01$ & & & \\
\hline & Kemampuan & a. Memotivasi mahasiswa & 6,23 & 12,45 & & \\
\hline & memotivasi & b. Tidak memotivasi & $-6,23$ & & $21,01 \%$ & 2 \\
\hline & manasiswa & $\mathrm{m}$ & Totol & 5020 & $100 \%$ & \\
\hline
\end{tabular}

Keterangan: Urutan terkecil=paling disukai

\subsection{Segmentasi Preferensi Mahasiswa terhadap Kualitas Dosen}

Segmentasi preferensi mahasiswa terhadap kualitas dosen ditinjau menurut karakteristik IPK, tingkat/kelas, asal SMA, jenis kelamin, dan kemampuan ekonomi (pendapatan) orang tuanya. Berikut ini penggambaran preferensi mahasiswa terhadap kualitas dosen pada tiap segmen berdasarkan Nilai Relatif Penting (NRP) setiap atribut:

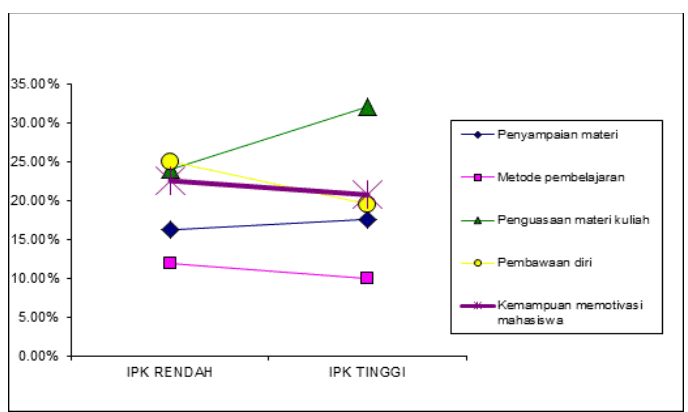

Gambar 1 Perbandingan preferensi mahasiswa terhadap kualitas dosen berdasarkan segmen IPK

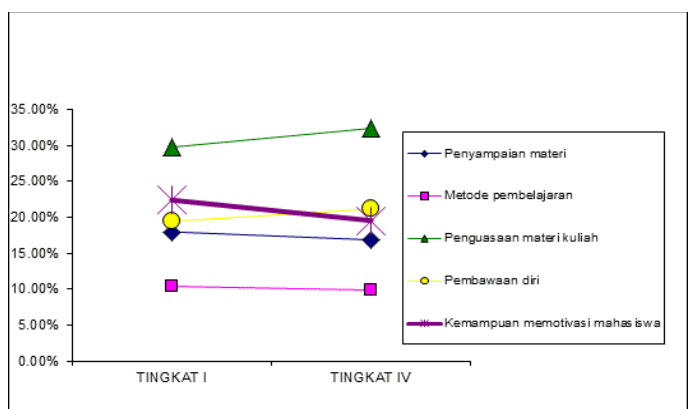

Gambar 2 Perbandingan preferensi mahasiswa terhadap kualitas dosen berdasarkan segmen tingkat 
Gambar 1 menunjukkan adanya kecenderungan mahasiswa yang mempunyai IPK tinggi paling menyukai dosen yang menguasai materi. Sedangkan mahasiswa yang mempunyai IPK rendah paling menyukai dosen yang pembawaan dirinya humoris. Bagi mahasiswa yang memiliki IPK tinggi, selain dosen yang menguasai materi, dosen yang mampu memotivasi mahasiswa dan pembawaan diri yang humoris lebih disukai. Sedangkan mahasiswa yang memiliki IPK rendah, penguasaan materi dan kemampuan memotivasi mahasiswa adalah atribut terpenting kedua dan ketiga yang disukainya dari profil seorang dosen. Kemudian pada tingkat keempat dan kelima atribut yag disukai, baik mahasiswa yang IPK-nya tinggi maupun rendah, keduanya menyukai dosen yang penyampaian materinya dengan komunikasi dua arah dan metode pembelajarannya kreatif.

Berdasarkan gambar 2, preferensi mahasiswa terhadap kualitas dosen ternyata berbeda pada mahasiswa tingkat I dan tingkat IV terutama pada atribut kedua dan ketiga. Mahasiswa tingkat I lebih menyukai dosen yang memotivasi mahasiswanya daripada dosen yang humoris. Sebaliknya, mahasiswa tingkat IV lebih menyukai dosen yang humoris daripada dosen yang memotivasi mahasiswanya. Hal ini diduga dikarenakan mahasiswa tingkat I memang membutuhkan motivasi pada masa-masa awal proses belajarnya di perguruan tinggi sedangkan mahasiswa tingkat IV lebih memerlukan suasana belajar yang santai dengan pembawaan diri dosen yang humoris pada masa-masa akhir proses belajarnya di perguruan tinggi.

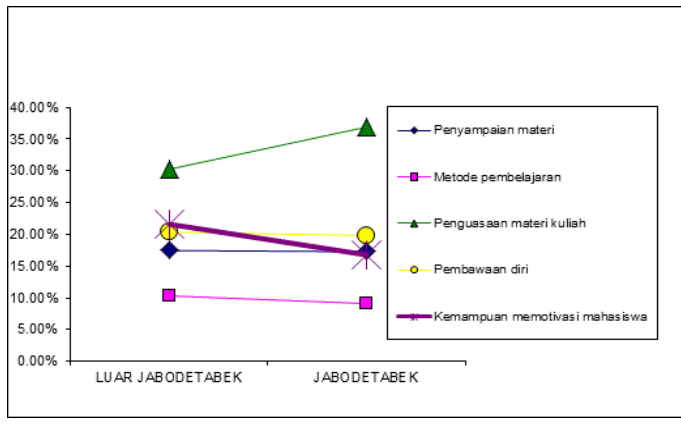

Gambar 3 Perbandingan preferensi mahasiswa terhadap kualitas dosen berdasarkan segmen asal SMA

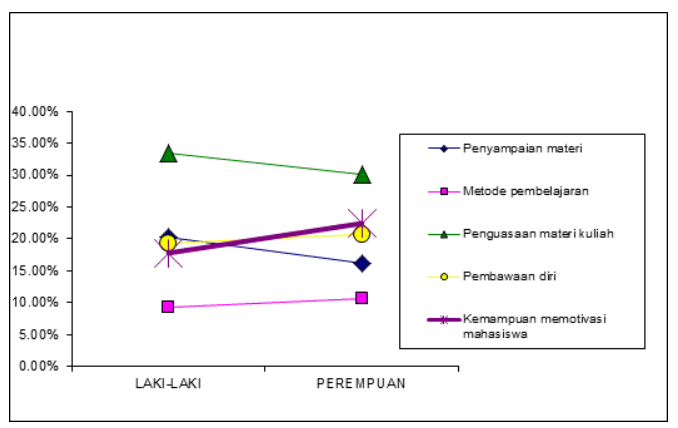

Gambar 4 Perbandingan preferensi mahasiswa terhadap kualitas dosen berdasarkan segmen jenis kelamin 
Pada gambar 3 dapat dideskripsikan bahwa mahasiswa yang asal SMA-nya di wilayah Jabodetabek lebih menyukai dosen yang humoris, penyampaian materi komunikatif, serta memotivasi mahasiswanya. Sedangkan mahasiswa yang asal SMA-nya di luar wilayah Jabodetabek lebih menyukai dosen yang mampu memotivasi mahasiswanya, humoris dan penyampaian materinya komunikatif. Hal ini diperkirakan karena mahasiswa yang asalnya dari luar Jabodetabek lebih membutuhkan motivasi terutama akibat jauhnya mereka dari lingkungan keluarga. Demikian pula dengan mahasiswa yang asalnya dari Jabodetabek, karena sudah terbiasa dengan lingkungan perkotaan bertekanan jiwa serta sosial yang tinggi, maka dosen yang humoris lebih membawa suasana kelas yang dapat mengurangi tekanan tersebut terutama dalam proses belajar.

Hal menarik dari preferensi mahasiswa terhadap kualitas dosen ditinjau dari segmen jenis kelamin seperti pada gambar 4 adalah mahasiswa laki-laki lebih menyukai dosen yang komunikatif (menyampaikan materi secara dua arah) daripada dosen yang suka memotivasi mahasiswanya. Sedangkan mahasiswa perempuan sebaliknya, lebih menyukai dosen yang suka memotivasi mahasiswanya daripada dosen yang komunikatif. Hal ini mungkin disebabkan karena mahasiswa perempuan lebih didominasi oleh perasaannya yang lebih membutuhkan motivasi daripada mahasiswa laki-laki yang didominasi oleh akal pikirannya.

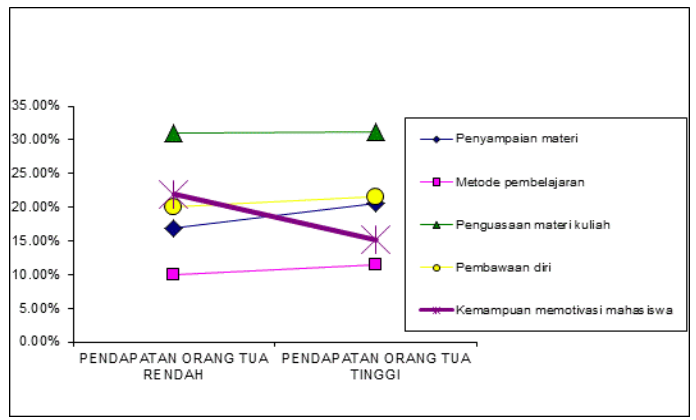

Gambar 5 Perbandingan preferensi mahasiswa terhadap kualitas dosen berdasarkan segmen pendapatan orang tua 
Seperti halnya pada segmentasi sebelumnya, perbedaan preferensi juga tampak pada segmen pendapatan orang tua. Pada gambar 5, mahasiswa yang orang tuanya berpendapatan rendah lebih menyukai dosen yang memotivasi mahasiswanya, humoris dan komunikatif. Sedangkan mahasiswa yang orang tuanya berpendapatan tinggi tampaknya lebih menyukai dosen yang humoris, komunikatif, dan kemudian mampu memotivasi mahasiswanya. Hal ini diduga terjadi karena pada kondisi ekonomi yang sulit, mahasiswa lebih membutuhkan motivasi dari dosennya daripada pada kondisi ekonomi yang berkecukupan. Sedangkan pada kondisi ekonomi yang memadai, kecenderungan manusia ingin memenuhi kebutuhan tersiernya seperti hiburan, kenyamanan, dan sebagainya.

\section{KESIMPULAN DAN SARAN}

Urutan preferensi mahasiswa terhadap kualitas dosen mencakup penguasaan materi kuliah, kemampuan memotivasi mahasiswa, pembawaan diri, penyampaian materi, dan metode pembelajaran. Mahasiswa dengan IPK tinggi menyukai dosen yang menguasai materi. Sedangkan mahasiswa dengan IPK rendah menyukai dosen yang pembawaan dirinya humoris. Mahasiswa tingkat I lebih menyukai dosen yang memotivasi mahasiswanya daripada dosen humoris. Sebaliknya, mahasiswa tingkat IV lebih menyukai dosen humoris daripada dosen yang memotivasi mahasiswanya. Mahasiswa yang asal SMA-nya dari wilayah Jabodetabek lebih menyukai dosen humoris. Sedangkan mahasiswa yang asal SMA-nya dari luar wilayah Jabodetabek lebih menyukai dosen yang mampu memotivasi mahasiswanya. Mahasiswa laki-laki lebih menyukai dosen yang komunikatif (menyampaikan materi secara dua arah) daripada dosen yang suka memotivasi mahasiswanya. Sebaliknya, mahasiswa perempuan lebih menyukai dosen yang suka memotivasi mahasiswanya daripada dosen yang komunikatif. Mahasiswa yang orang tuanya berpendapatan rendah lebih menyukai dosen yang memotivasi mahasiswanya. Sedangkan mahasiswa yang orang tuanya berpendapatan tinggi lebih menyukai dosen yang humoris. 


\section{DAFTAR PUSTAKA}

Aaker DA, Day GS. 1980. Marketing Research. New York : John Willey\&Son, Inc.

Chaplin JP. 2002. Kamus Lengkap Psikologi. Edisi kelima. Terjemahan: dr. Kartini Kartono. Jakarta: PT. Raja Grafindo Persada.

[DPPM] Direktorat Penelitian dan Pengabdian pada Masyarakat. 2002. Kebijakan dan Program Penelitian dan Pengabdian kepada Masyarakat. Jakarta: Departemen Pendidikan Nasional

http://www.sawtooth.com, Conjoint Analysis, 2001.

Kuhfeld WF. 2000. “Conjoint Analysis Examples”, SAS Institut, Inc. http://www. sawtooth software.com. [28 Januari 2004]

Pujadi A. 2007. Faktor-Faktor yang Mempengaruhi Motivasi Belajar Mahasiswa: Studi Kasus pada Fakultas Ekonomi Universitas Bunda Mulia. Business \& Management Journal Bunda Mulia, Vol: 3, No. 2.

Rosada R. 2002. Perbandingan Metode Pairwise Comparison dan Full profile dalam Pengumpulan Data untuk Analisis Konjoin. Skripsi. Jurusan Statistika IPB. Bogor.

Sudiana IN. 2003. Peranan Profesionalisme Tenaga Pengajar (Dosen) terhadap Proses Pembelajaran di Perguruan Tinggi. Jurnal Pendidikan dan Pengajaran IKIP Negeri Singaraja, No. 4 TH. XXXVI.

Wibisono D. 2003. Riset Bisnis. Jakarta : PT. Gramedia Pustaka Utama. 